\section{Soil Amendments and Fertilizer Source Effects on Creeping Bentgrass Establishment, Soil Microbial Activity, Thatch, and Disease}

\author{
John E. Kaminski and Peter H. Dernoeden ${ }^{1}$
}

Department of Natural Resource Sciences and Landscape Architecture, University of Maryland, College Park, MD 20742

\section{Cale A. Bigelow}

Agronomy Department, Purdue University, West Lafayette, IN 47907

Additional index words. turfgrass, golf green, natural organic and synthetic fertilizers

Abstract. Natural organic fertilizers require microbial degradation for nitrogen (N) release, but their ability to promote rapid turfgrass establishment has not been well documented in newly constructed sand-based rootzones. This 2-year field study evaluated the influence of two general fertilizer and soil amendment programs for their effect on establishment and quality of three creeping bentgrass (Agrostis stolonifera L.) cultivars-'Crenshaw', 'Penn G-2', and 'Providence'. Turf was grown on a 4 sand : 1 sphagnum peat (by volume) rootzone mixture. Four treatments consisting of surface-applied synthetic fertilizer (SF; mostly water-soluble $\mathrm{N}$ in 1999 and methylene urea thereafter); surface-applied hydrolyzed poultry meal $(\mathrm{PM})$; preplant-incorporated granular humate $(\mathrm{GH})$ with surface-applied SF ; and preplant-incorporated PM with surface-applied PM. Turf cover data collected 42 days after seeding (DAS) showed that the rate of establishment was SF+GH incorporated $=$ SF surface-applied $>$ PM surface-applied + PM incorporated $>$ PM surface-applied. Turf cover was $\geq 96 \%$ among all treatments 90 DAS. Rootmass density was greater (18\% to $29 \%$ ) at 103 DAS in GH incorporated plots combined with SF, when compared to all other treatments, but no rootmass differences subsequently were observed. Soil microbial activity generally was highest in PM-treated plots during the first 14 months following seeding, but not thereafter. Turf treated with SF had less microdochium patch (Microdochium nivale (Fr.) Samuels and I.C. Hallett) and more bentgrass dead spot (Ophiosphaerella agrostis Dernoeden, M.P.S. Camara, N.R. O'Neill, van Berkum et M.E. Palm), when compared to PM-treated plots. Slightly less thatch developed in PM-treated turf when compared to plots receiving SF alone by the end of the second year. Penn G-2 and SF generally provided the best overall turf quality. This study demonstrated the beneficial effects of readily available $\mathrm{N}$ from $\mathrm{SF}$ for rapid establishment and that preplant incorporation of GH initially aided root development.

Golf greens normally are constructed with high sand content rootzone mixtures $(>80 \%$ by volume) to resist compaction and maintain drainage (USGA Green Section Staff, 1993). Despite the aforementioned benefits of a sand-based rootzone, these synthetically prepared soils initially may support a less numerous microbial community than native soils because of their reduced organic matter and clay contents (Alexander, 1977). Organic matter additions have been shown to increase soil microbial activity, water retention, cation exchange capacity, nutrient transformation, cycling and retention, and pesticide degradation (Elliott and Des Jardin, 2001; Mancino et al., 1993; Stevenson, 1994). The positive effects of organic substances like humates on plant

Received for publication 6 Jan. 2003. Accepted for publication 23 July 2003. Mention of trademark or proprietary product does not constitute a guarantee or warranty of the product by the University of Maryland or the authors and does not imply its approval to the exclusion of other products that also may be suitable. A contribution of the Maryland Agricultural Experiment Station.

'Corresponding author; e-mail pd9@umail.umd.edu. these earlier studies are useful, however, these studies were of relatively short duration and the longer term effects of these materials on rooting under field conditions where adequate nutrients are supplied is unclear.

In addition to humic sources for amending sand-based rootzones, there is an industry trend to supply turfgrass nutrients as naturally occurring organic $\mathrm{N}$ sources, like hydrolyzed poultry meal (PM) products. Besides being $\mathrm{N}$ sources, the suppressive effects of these materials on common turfgrass diseases like dollar spot (Sclerotinia homoeocarpa F.T. Bennett) have been reported (Davis and Dernoeden, 2002; Hoyland and Landschoot, 1993; Liu et al., 1995; Nelson and Craft, 1991, 1992). The disease suppressive effects in these studies were attributed to several factors including stimulation of shoot growth by the $\mathrm{N}$ components of these products, the introduction of antagonistic microbes, stimulation of native microbes or a combination of one or more of these factors. Liu et al.(1995) found higher microbial populations on the leaves, thatch and soil of turf treated with a poultry meal-based fertilizer, ammonium nitrate or sulfur-coated urea compared to other fertilizers. They suggested that this increase in microbial population may be related to the dollar spot suppression observed in the study. Davis and Dernoeden (2002) found that a natural-organic PM product delayed dollar spot incidence and reduced outbreaks to within an acceptable threshold when disease pressure was low to moderately severe. The response, however, was not significantly different than urea or sulfur coated urea. They also found that none of the N sources tested were consistently associated with higher soil microbial activity and concluded that $\mathrm{N}$ availability was more important than soil microbial activity in suppressing dollar spot. The aforementioned studies, however, were conducted on mature turfgrasses grown on older sand rootzones or native soils.

While dollar spot can be a chronic problem on creeping bentgrass, take-all (Gaeumannomyces graminis (Sacc.) Arx and D. Olivier var. avenae (E.M. Turner) Dennis) and bentgrass dead spot often are a problem on newly constructed greens or older greens that have been fumigated with methyl bromide (Kaminski and Dernoeden, 2002; Smiley et al., 1992; Smith et al., 1989). In both cases, these diseases often are most severe in the first few years after seeding and generally decline in subsequent years. This decline is believed to be in response to increasing soil microbial populations (Kaminski and Dernoeden, 2002; Smiley et al., 1992; Smith et al., 1989). Little information exists regarding the influence of $\mathrm{N}$ source on disease suppression and soil microbial activity during creeping bentgrass establishment in a sand-based medium.

Many turfgrass managers are curious about the potential benefits of using natural-organic fertilizers as their sole $\mathrm{N}$ source for nutrition during establishment, and the long term effects on disease suppression, soil microbial activity, thatch production and aesthetic turfgrass growth properties. The objectives of this study were to compare the effects of various 
incorporated and surface-applied fertilizers and granular humate on creeping bentgrass establishment and maintenance in a new sand-based rootzone. Additionally, this study assessed the influence of a synthetic and natural organic fertility program on the incidence and severity of diseases. The treatments were as follows: a natural organic PM-based fertilizer; a conventional synthetic fertilizer (SF) program similar to that used by turf mangers in the midAtlantic region; and preplant incorporation of either GH or PM, with or without surface applications of PM and SF.

\section{Materials and Methods}

This study was conducted at the University of Maryland Paint Branch Turfgrass Research Facility, College Park, Md., from September 1999 through December 2001. An experimental putting green [4 sand: 1 sphagnum peat (by volume)] was constructed in the summer of 1999 according to USGA (1993) guidelines. Initial $\mathrm{P}$ and $\mathrm{K}$ levels were 39 and $4 \mathrm{~kg} \cdot \mathrm{ha}^{-1}$, respectively.

Twelve whole plots $(1.5 \times 12 \mathrm{~m})$ were established to evaluate the effect of four fertilizer-soil amendment treatments on three creeping bentgrass cultivars. The subplot $(1.5 \times 3.0 \mathrm{~m})$ fertilizer-soil amendment treatments consisted of 1) SF surface-applied at a N rate of $49 \mathrm{~kg} \cdot \mathrm{ha}^{-1}$ (initially a starter fertilizer, $19 \mathrm{~N}-11 \mathrm{P}-4 \mathrm{~K}$, $4.3 \%$ ammoniacal $\mathrm{N} ; 7.4 \%$ urea $\mathrm{N} ; 6.3 \%$ other water soluble N; $1.0 \%$ water insoluble N, $1.8 \%$ elemental S, Scotts Co., Marysville, Ohio), 2) $\mathrm{GH}$ (Menefee humate, $0.9 \mathrm{~N}-0.1 \mathrm{P}-0.1 \mathrm{~K}$; CEC $61 \mathrm{cmol} \cdot \mathrm{kg}^{-1} ; 715 \mathrm{~g} \cdot \mathrm{ha}^{-1}$ organic matter, Earthgreen Products Inc., Dallas) incorporated to a depth of $6.5 \pm 1.5 \mathrm{~cm}$ at $2000 \mathrm{~kg} \cdot \mathrm{ha}^{-1}$ with SF surface-applied at a $\mathrm{N}$ rate of $\left.49 \mathrm{~kg} \cdot \mathrm{ha}^{-1}, 3\right)$ a natural-organic hydrolyzed PM(Ringer Greens Super, $10 \mathrm{~N}-1 \mathrm{P}-5 \mathrm{~K} ; 1.5 \%$ water soluble organic $\mathrm{N} ; 8.5 \%$ water insoluble $\mathrm{N}$, containing selected proprietary strains of Bacillus subtilis, other Bacillus spp. and Trichoderma viride at a minimum of $1.5 \times 10^{6} / \mathrm{g}$ of fertilizer, Ringer Corp., Minneapolis) surface-applied at $490 \mathrm{~kg} \cdot \mathrm{ha}^{-1}$, and 4) PM incorporated at a rate of $980 \mathrm{~kg} \cdot \mathrm{ha}^{-1}$ to a depth of $6.5 \pm 1.5 \mathrm{~cm}$. The preplant amendment treatments were incorporated by hand using a hard steel rake to thoroughly distribute the products throughout the mixture to the aforementioned depth. Following the incorporation of amendments, the surface was smoothed and compacted to the surrounding original grade. Fertilizers were applied using a shaker bottle and treated areas were irrigated immediately following application. A full complement of all possible treatment combinations was not evaluated due to space constraints in the experimental putting green. An unfertilized control was not included for comparison because $\mathrm{N}-\mathrm{P}-\mathrm{K}$ are routinely used for turfgrass establishment and maintenance.

The soil had $10 \%$ organic matter and an initial soil $\mathrm{pH}$ of 4.9. Following initial fertilizer-soil amendment applications, 'Penn G-2', 'Providence' and 'Crenshaw' were seeded in monostands on 10 Sept. 1999 at a rate of 50 to $55 \mathrm{~kg} \cdot \mathrm{ha}^{-1}$. Borders ( $60 \mathrm{~cm}$ wide) of 'Bardot' colonial bentgrass (Agrostis capillaris L.) were planted between cultivar treatments and $90 \mathrm{~cm}$ wide borders were established between each block. The creeping bentgrass cultivars were selected based on their prevalence for putting green use in the mid-Atlantic region. Once seeded, the area was covered with $100 \%$ spunbonded polypropylene blankets (Reemay Inc., Old Hickory, Tenn.) and overhead irrigation was applied routinely for 1 week until seedling emergence. The polypropylene blankets were removed $\approx 1$ week after seedling emergence. The area initially was mowed on 21 Oct. to a height of $2.5 \mathrm{~cm}$ with a rotary mower and adjusted to 1.2 $\mathrm{cm}$ using a light-weight walking greensmower (Toro 500; Toro Inc., Minneapolis) and mowed as needed for the remainder of 1999. Following establishment and complete coverage, the area was mowed three times weekly at $\approx 5.0 \mathrm{~mm}$. Other periodic maintenance practices included sand-topdressing, core aeration, vertical cutting, and irrigation to prevent drought stress. Chlorothalonil (tetrachloroisophthalonitrile) or myclobutanil ( $\alpha$-butyl- $\alpha$ (chlorophenyl)-1H-1,2,4, triazole-1-propanenitrile) were applied at label rates to control dollar spot and microdochium patch after data collection to prevent severe turf injury.

During establishment in 1999, all fertilizer treatments were applied at a N rate of $49 \mathrm{~kg}^{\circ} \mathrm{ha}^{-1}$ on 23 Sept., 8 and 15 Oct., and 19 Nov. Plots receiving the mostly water-soluble SF with a starter analysis also received supplemental $\mathrm{K}$ from potassium sulfate $(0 \mathrm{~N}-0 \mathrm{P}-42 \mathrm{~K})$ and $\mathrm{PM}-$ treated plots received supplemental $\mathrm{P}$ as triple super phosphate $(0 \mathrm{~N}-20 \mathrm{P}-0 \mathrm{~K})$ to balance the $\mathrm{P}$ and $\mathrm{K}$ levels for each fertilizer. Hence, when turf was fertilized with N, 20 and $6.0 \mathrm{~kg}^{-1} \mathrm{ha}^{-1}$ $\mathrm{P}$ and $\mathrm{K}$ also were supplied, respectively. Due to generally slow establishment, especially in PM-surface-applied plots, SF-N was applied (49 $\mathrm{kg} \cdot \mathrm{ha}^{-1}$ ) to all plots on 1 Oct. 1999.

Beginning in the spring following fall establishment, the SF N source was changed to methylene urea $(40 \mathrm{~N}-0 \mathrm{P}-0 \mathrm{~K}$, Nutralene, The Anderson's Inc., Maumee, Ohio), a slow release synthetic fertilizer. Methylene urea has similar N-release characteristics to PM, but does contain $\approx 6 \%$ water soluble $\mathrm{N}$. This change was instituted to determine differences in disease incidence, thatch production and turf quality between synthetic and natural organic slow release fertilizers under a maintenance fertility program in 2000 and 2001. Supplemental $P$ and K were added as described previously. In 2000, all fertilizers were applied at an $\mathrm{N}$ rate of 24 $\mathrm{kg} \cdot \mathrm{ha}^{-1}$ on 15 May and $12 \mathrm{~kg} \cdot \mathrm{ha}^{-1}$ about every 2 weeks from 9 June through 8 Sept., followed with $37 \mathrm{~kg} \cdot \mathrm{ha}^{-1}$ on 27 Sept., and 6 and 20 Oct. In 2001, all fertilizers were applied at an $\mathrm{N}$ rate of $49 \mathrm{~kg} \cdot \mathrm{ha}^{-1}$ on 1 May, followed by $24 \mathrm{~kg} \cdot \mathrm{ha}^{-1}$ on 6 June and $12 \mathrm{~kg} \cdot \mathrm{ha}^{-1}$ about every 2 weeks from 18 June through 21 Aug., followed with $24 \mathrm{~kg} \cdot \mathrm{ha}^{-1}$ on 4 and 17 Sept. Total fertilizer applied was $220 \mathrm{~N}-19 \mathrm{P}-54 \mathrm{~K}$ and $210 \mathrm{~N}-17 \mathrm{P}-49 \mathrm{~K} \mathrm{~kg} \cdot \mathrm{ha}^{-}$ for 2000 and 2001, respectively. Limestone was applied to all plots at 490 and $590 \mathrm{~kg} \cdot \mathrm{ha}^{-1}$ on 19 Nov. 1999 and 29 Mar. 2000, respectively. Mean soil pH increased from 4.9 to 6.9 by 25 Sept. 2000

Plant measurements. Percent cover was rated visually until full cover was achieved in
Dec. 1999 using a linear 0 to 100 scale, where $0=$ bare ground and $100=$ complete cover Additionally, visual turfgrass quality was rated twice monthly between April and Novembe and monthly from December to April using a scale of 0 to 10 , where $0=$ brown or dead turf and $10=$ uniform, optimum green color and density. Values for each plot were combined and averaged for actual calendar-based seasons as follows: spring (20 Mar. through 20 June), summer (21 June through 21 Sept.), fall (22 Sept. through 21 Dec.), and a yearly mean. Averaged turfgrass quality values for each season were used for the statistical analysis.

Turfgrass disease assessments were recorded periodically throughout the study whenever a disease was active. The diseases observed included dollar spot, microdochium patch, bentgrass dead spot, and superficial fairy ring (fungal species not identified). All diseases were the result of naturally occurring infection except for bentgrass dead spot. In June 2000 the study area was inoculated with an isolate of $O$. agrostis. The inoculum was prepared as described by Kaminski and Dernoeden (2002). About $0.5 \mathrm{~g}$ of inoculum was placed below the turfgrass canopy at the soil-thatch level on $0.6 \mathrm{~m}$ centers for a total of four infection locations/plot. Depending on disease severity, plots were rated either by counting the number of infection centers for bentgrass dead spot or visually estimating the percentage of plot area affected using a $0 \%$ to $100 \%$ linear scale for the other diseases.

To assess the effect of fertilizer-soil amendments on initial bentgrass rooting, average and maximum root length were measured on 24 Nov. 1999. These values were determined by removing two samples from each plot with a soil profile sampler $(7.6 \mathrm{~cm}$ wide, $15.2 \mathrm{~cm}$ deep, and $1.3 \mathrm{~cm}$ thick) and combining values for a plot average. Average root length was determined following gentle agitation to remove the rootzone media. The maximum root length was measured with a ruler as the deepest visible root. In addition, rootmass was determined on 22 Dec. 1999 by removing three profile-type samples per plot. This profile sampling device initially was used because a standard circula core sampler would not consistently remove an intact core. Subsequent seasonal rootmass measurements were determined by a core removal technique. Five core samples $(1.9 \mathrm{~cm}$ diamete $\times 25 \mathrm{~cm}$ )/plot were taken on 17 June 2000 and nine core samples per plot were taken on 11 Aug. 2000 and 29 Mar., 21 June, and 19 Oct 2001. Crown and leaf tissues were removed and the rootzone mixture was thoroughly washed from roots over a 1-mm sieve. Roots then were dried for 1 week at $60^{\circ} \mathrm{C}$ and visible peat moss particles were removed by hand and weighed. Samples were placed in a $500{ }^{\circ} \mathrm{C}$ ashing oven overnight and reweighed. Subsample values were combined and the average root weigh was used for the statistical analysis. Final root weights were converted to a mass volume basis, hereafter referred to as rootmass density and expressed as $\mathrm{kg} \cdot \mathrm{m}^{-3}$.

Thatch. Thatch depth was measured 15 Sept. 2000 and 21 June and 19 Oct. 2001. Nine core $(1.9 \mathrm{~cm}$ diameter $\times 8 \mathrm{~cm}$ deep $)$ were removed 
from each plot and the uncompressed thatch depth of each core was measured with a ruler to the nearest $\mathrm{mm}$. The average thatch depth per plot was used for statistical analysis.

Soilmicrobialmeasurements. Soilmicrobial activity was measured periodically throughout the study from the Crenshaw plots only. This cultivar was selected for analysis based on its known susceptibility to dollar spot and other potential diseases. It was hypothesized that if any beneficial disease suppressive effects were present, they may be more noticeable in this cultivar. Plots were sampled on 27 Oct. and 24 Nov. 1999; 9 June, 1 Sept., and 29 Nov. 2000; and 5 Apr., 23 May, 28 June, 16 Aug., and 28 Sept. 2001. Samples were collected by randomly removing five soil cores $(1.9 \mathrm{~cm}$ diameter $\times 8$ $\mathrm{cm}$ deep) from each plot. The samples were taken immediately to the lab where the foliage and thatch were removed with a knife and the remaining soil processed. Microbial activity was determined by the fluorescein diacetate (FDA) hydrolysis method (Schnurer and Rosswall, 1982) with minor modifications. A more detailed description of the specific methodology can be found in Davis and Dernoeden (2002)

Statistical design and analysis. All data were subjected to analysis of variance (ANOVA) by the Statistical Analysis System (SAS Institute, 1999). The experimental design was a randomized complete split-block design with four replications for each treatment. Within each block, cultivar whole plots were arranged in a randomized complete block and amendment subplots were arranged in a completely randomized design within each cultivar. Data were analyzed for significant treatment $\times$ year interactions and treatment means were separated by Fisher's least significant difference test (LSD) and preplanned orthogonal comparisons comparing all SF vs. PM treatments, preplant soil amendments vs. no preplant soil amendments and preplant GH vs. PM alone (Steel et al., 1997). Due to significant treatment $\times$ year effects, most data are presented individually for each year.

\section{Results and Discussion}

Establishment. The SF treatments generally resulted in the most rapid establishment, particularly during the first 35 DAS (Table 1). Granular humate-incorporated plots plus SF surface-applied resulted in a greater establishment rate, when compared to the either

Table 1. Visual cover ratings of three creeping bentgrass cultivars grown on a sand-based rootzone mixture as influenced by fertilizer and preplant soil amendment applications, 1999

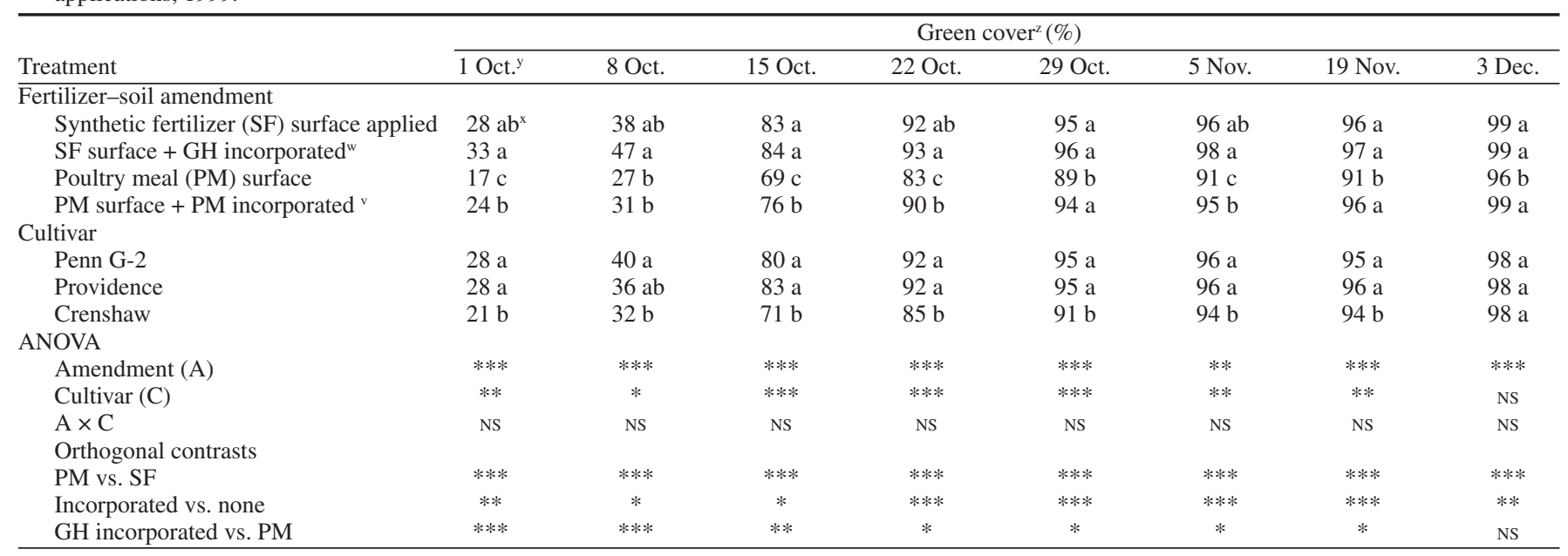

Cover was rated visually on a 0 to 100 scale, where $0=$ bare soil and $100=$ complete turfgrass coverage.

${ }^{y}$ Creeping bentgrass was seeded on 10 Sept. 1999.

${ }^{x}$ Means in the same column followed by the same letter are not significantly different according to Fisher's protected LSD $(P=0.05)$.

"Granular humate $(\mathrm{GH})$ was incorporated at $2000 \mathrm{~kg}^{\circ}$ ha ${ }^{-1}$ into the top $6.5 \mathrm{~cm}$ of the rootzone.

voultry meal was incorporated at $980 \mathrm{~kg} \cdot \mathrm{ha}^{-1}$ into the top $6.5 \mathrm{~cm}$ of the rootzone.

Ns,*******Nonsignificant or significant at $P=0.05,0.01,0.001$, respectively.

Table 2. Root length and root mass density of three creeping bentgrass cultivars grown on a sand-based rootzone as influenced by fertilizers and soil amendments.

\begin{tabular}{|c|c|c|c|c|c|c|}
\hline \multirow{2}{*}{ Treatment } & \multirow{2}{*}{\multicolumn{2}{|c|}{$\begin{array}{c}24 \text { Nov. } 1999 \\
\text { Root length }(\mathrm{cm})\end{array}$}} & \multicolumn{4}{|c|}{ Root mass density $\left(\mathrm{kg} \cdot \mathrm{m}^{-3}\right)$} \\
\hline & & & $\frac{1999}{22 \text { Dec. }}$ & \multicolumn{3}{|c|}{2001} \\
\hline \multicolumn{7}{|l|}{ Fertilizer-soil amendment } \\
\hline SF surface + GH incorporated ${ }^{y}$ & $7.1 \mathrm{a}$ & $11.7 \mathrm{a}$ & $0.51 \mathrm{a}$ & $1.17 \mathrm{a}$ & $1.13 \mathrm{a}$ & $0.59 \mathrm{a}$ \\
\hline Poultry meal (PM) surface & $6.4 \mathrm{ab}$ & $11.4 \mathrm{a}$ & $0.39 \mathrm{bc}$ & $1.08 \mathrm{a}$ & $1.03 \mathrm{a}$ & $0.56 \mathrm{a}$ \\
\hline PM surface + PM incorporated ${ }^{x}$ & $6.7 \mathrm{ab}$ & $10.3 \mathrm{~b}$ & $0.36 \mathrm{c}$ & $1.07 \mathrm{a}$ & $1.03 \mathrm{a}$ & $0.61 \mathrm{a}$ \\
\hline \multicolumn{7}{|l|}{ Cultivar } \\
\hline Crenshaw & $6.1 \mathrm{~b}$ & $10.7 \mathrm{~b}$ & $0.45 \mathrm{a}$ & $1.13 \mathrm{a}$ & $1.19 \mathrm{a}$ & $0.62 \mathrm{a}$ \\
\hline \multicolumn{7}{|l|}{ ANOVA } \\
\hline Amendment (A) & $*$ & $*$ & *** & NS & NS & NS \\
\hline Cultivar (C) & *** & $*$ & $*$ & NS & **** & $* * *$ \\
\hline $\mathrm{A} \times \mathrm{C}$ & NS & $*$ & NS & NS & NS & NS \\
\hline \multicolumn{7}{|l|}{ Orthogonal contrasts } \\
\hline $\mathrm{PM}$ vs. SF & NS & $*$ & $* * *$ & * & $*$ & NS \\
\hline
\end{tabular}

${ }^{2}$ Means in the same column followed by the same letter are not significantly different according to Fisher's protected $1 \mathrm{sd}(P=0.05)$

Granular humate $(\mathrm{GH})$ was incorporated at $2000 \mathrm{~kg}^{\circ} \mathrm{ha}^{-1}$ into the top $6.5 \mathrm{~cm}$ of the rootzone.

${ }^{x}$ Poultry meal was incorporated at $980 \mathrm{~kg} \cdot h \mathrm{~h}^{-1}$ into the top $6.5 \mathrm{~cm}$ of the rootzone.

Ns,********Nonsignificant or significant at $P=0.05,0.01,0.001$, respectively. 
PM treatment on five of eight rating dates. Plots in which PM was incorporated had higher cover ratings on nearly all dates, when compared to plots receiving the PM surfaceapplied treatment. When applied only to the surface, PM-treated plots exhibited the slowest establishment rate on nearly all rating dates. The slower establishment rate associated with $\mathrm{PM}$ was probably due to its slow $\mathrm{N}$ release characteristic, which relies on soil microbes for $\mathrm{N}$ release. In 1999, the SF used contained mostly readily available water soluble $\mathrm{N}$, which provided more rapid $\mathrm{N}$ availability and as expected more rapid turf coverage. Establishment was most rapid during the first 42 DAS, with the greatest differences between SF and PM being observed during the first 35 DAS. Differences in establishment diminished with time, and all treatments had $\geq 96 \%$ coverage by 3 Dec. Preplant incorporation of either PM or GH significantly improved establishment vs. no preplant amendment. Over time, however, the differences in establishment were small and probably not agronomically important. Among preplant soil amendment treatments, plots treated with $\mathrm{GH}$ plus SF established more rapidly than PM plus preplant PM. This probably was due to the use of a water soluble SF rather than a difference in the amendments since establishment with the GH treatment was the same as SF alone. Differences in the rate of establishment among cultivars were observed on nearly all rating dates, with 'Crenshaw' consistently exhibiting slowest establishment.

Rooting. On 24 Nov. 1999, the greatest average root length resulted from the incorporation of GH combined with SF, when compared to SF alone (Table 2). Both PM treatments resulted in an intermediate average root length, which were equivalent to the $\mathrm{GH}+\mathrm{SF}$ treatment. For maximum root length measurements, all treatments had slightly longer roots $(\geq 1.1 \mathrm{~cm})$ when compared to the PM incorporated treatment. Among the cultivars, 'Penn G-2' and 'Providence' had longer average root lengths than 'Crenshaw', but there was no difference between 'Providence' and 'Penn G-2'.

There were large differences in rootmass density among sampling dates (Table 2). Statistical comparison among some dates, however, was inappropriate due to the different sampling techniques initially used in the study Regardless, there were differences among fertilizer-soil amendments and cultivars on three of four sampling dates. The effect was most pronounced on the first sampling date (103 DAS). On this date (22 Dec.), GH combined with surface-applied SF resulted in a greater rootmass density ( $21 \%$ to $42 \%$ ), when compared to the other treatments. Among cultivars, 'Crenshaw' had a greater rootmass density ( $10 \%$ to $13 \%)$, than the other two cultivars on this date. No rootmass density differences were observed among treatments in 2000 (data not shown). Orthogonal contrasts comparing SF vs. PM, however, showed that bentgrass treated with SF had greater rootmass density when compared to PM-treated turf on 29 Mar. and 21 June 2001. On the aforementioned dates, orthogonal contrasts revealed that bentgrass established with GH had a greater rootmass density than turf in plots receiving PM. These rootmass density results were consistent with previous investigations involving $\mathrm{GH}$ and natural organic fertilizers during bentgrass establishment in sand-based rootzones (Dorer and Peacock, 1997; Cooper et al., 1998).

Table 3. Soil microbial activity as measured by fluorescein diacetate (FDA) hydrolysis in a sand-based rootzone as influenced by fertilizers and soil amendments in 'Crenshaw' creeping bentgrass.

\begin{tabular}{|c|c|c|c|c|c|}
\hline \multirow[b]{3}{*}{ Treatment } & \multicolumn{5}{|c|}{ FDA hydrolyzed ( $\mu \mathrm{g} \cdot \mathrm{g}^{-1}$ soil per min) } \\
\hline & \multicolumn{2}{|c|}{1999} & \multicolumn{3}{|c|}{2000} \\
\hline & 27 Oct. & 24 Nov. & 9 June & 1 Sept. & 29 Nov. \\
\hline \multicolumn{6}{|l|}{ Fertilizer-soil amendment } \\
\hline SF surface + GH incorporated ${ }^{y}$ & $0.291 \mathrm{~b}$ & $0.781 \mathrm{~b}$ & $3.603 \mathrm{ab}$ & $3.891 \mathrm{a}$ & $2.005 \mathrm{bc}$ \\
\hline Poultry meal (PM) surface & $0.617 \mathrm{ab}$ & $1.191 \mathrm{ab}$ & $4.672 \mathrm{a}$ & $3.481 \mathrm{a}$ & $2.457 \mathrm{ab}$ \\
\hline PM surface + PM incorporated ${ }^{x}$ & $0.959 \mathrm{a}$ & $2.170 \mathrm{a}$ & $3.470 \mathrm{ab}$ & $3.625 \mathrm{a}$ & $3.240 \mathrm{a}$ \\
\hline \multicolumn{6}{|l|}{ ANOVA } \\
\hline PM vs. SF & $*$ & $*$ & $*$ & NS & $* *$ \\
\hline Incorporated vs. none & NS & NS & NS & NS & $*$ \\
\hline GH incorporated vs. PM & $* *$ & $* *$ & NS & NS & $* *$ \\
\hline
\end{tabular}

${ }^{2}$ Means in the same column followed by the same letter are not significantly different according to Fisher's protected $1 \mathrm{sd}(P=0.05)$

${ }^{y}$ Granular humate $(\mathrm{GH})$ was incorporated at $2000 \mathrm{~kg} \cdot \mathrm{ha}^{-1}$ into the top $6.5 \mathrm{~cm}$ of the rootzone.

${ }^{x}$ Poultry meal was incorporated at $980 \mathrm{~kg} \cdot \mathrm{ha}^{-1}$ into the top $6.5 \mathrm{~cm}$ of the rootzone.

Ns,*,******Nonsignificant or significant at $P=0.05,0.01,0.001$, respectively.

Table 4. Thatch depth in three creeping bentgrass cultivars grown on a sand-based rootzone as influenced by fertilizers and soil amendments.

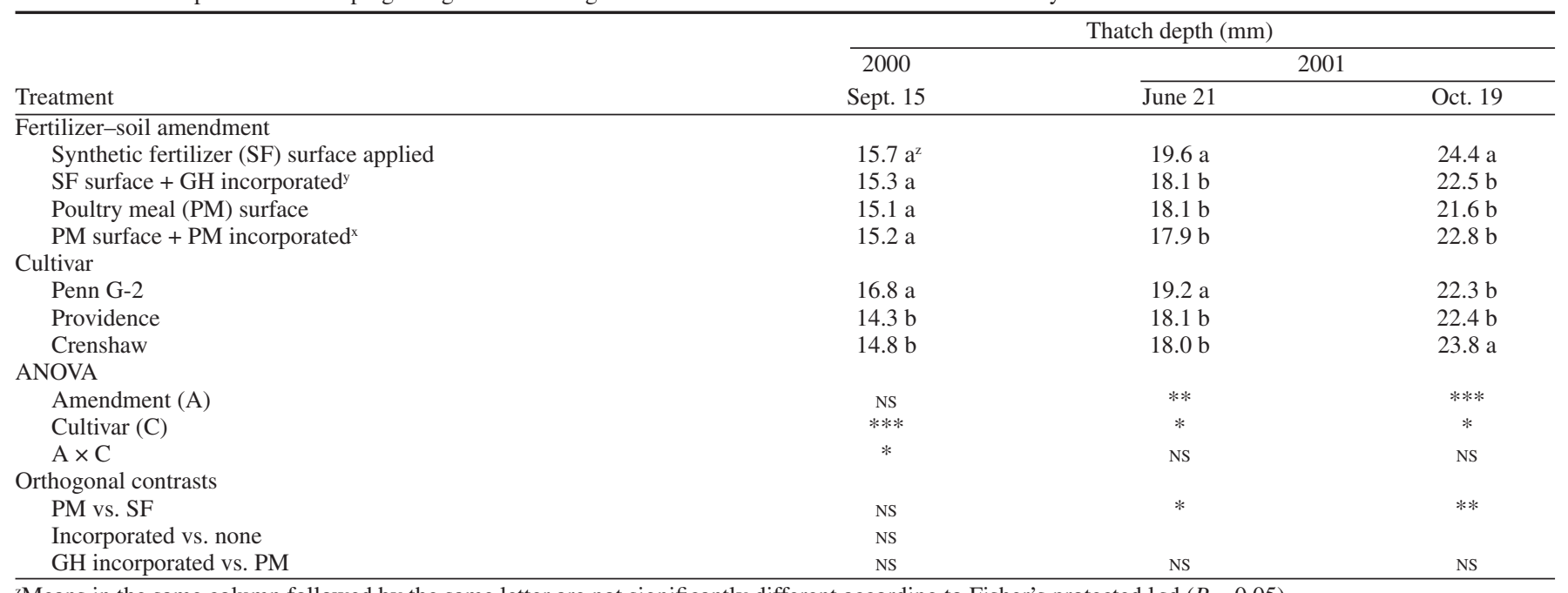

${ }^{2}$ Means in the same column followed by the same letter are not significantly different according to Fisher's protected $1 \mathrm{sd}(P=0.05)$

${ }^{\mathrm{y}} \mathrm{GH}=$ granular humate; incorporated at $2000 \mathrm{~kg} \cdot \mathrm{ha}^{-1}$ into the top $6.5 \mathrm{~cm}$ of the rootzone.

${ }^{x}$ Poultry meal was incorporated at $980 \mathrm{~kg} \cdot \mathrm{ha}^{-1}$ into the top $6.5 \mathrm{~cm}$ of the rootzone.

Ns,***,****Nonsignificant or significant at $P=0.05,0.01,0.001$, respectively. 
A seasonal decline in rootmass density between spring to late summer and fall was observed in both years. In 2000, this decline was rather small (7\% to $15 \%$ ), depending on treatment (data not shown). The response in 2001, however, was highly significant $(P<$ $0.01)$ and a loss in rootmass density $(41 \%$ to $50 \%$ ) was observed between June and Oct. This rootmass loss in response to increasing summer temperatures is common for cool-season grasses and has been documented in creeping bentgrass (Sweeney et al., 2001). Factors such as declining soil aeration status of the aging rootzone or indirect high temperature stress probably contributed to root loss (Beard and Daniel 1966; Ralston and Daniel, 1972; Kurtz and Kneebone, 1980; Huang et al., 1998; Xu and Huang, 2000; Bigelow et al., 2001).
Soilmicrobial activity. Soil microbial activity increased from October 1999 to September 2000 , with a substantial $(P<0.05)$ decline observed in November 2000. Significant microbial activity effects due to fertilizer and soil amendment treatments only were observed during the first 14 months of sampling (Table 3). Soil in the PM-incorporated treated plots had higher microbial activity than soil incorporated with GH in 1999. Soil in PM-treated plots had higher microbial activity levels than SF-treated plots on two of three rating dates in 2000. This may have been due in part to the presence of indigenous microbes in the PM fertilizer used in this study. Microbial activity resumed to previous or slightly greater levels for the remainder of the study with no treatment differences observed in 2001 (data not shown)
These early, temporal fluctuations of microbial activity and subsequent stable values were consistent with other studies in which microbial properties were evaluated during initial turfgrass establishment in sand-based rootzones (Bigelow et al., 2002; Elliott and Des Jardin, 1999, 2001; Elliottet al, 2000; Mancino et al., 1993). The levels of soil microbial activity in the sand-based rootzone were somewhat lower ( 1 to $4 \mu \mathrm{g}$ FDA hydrolyzed/min per $g$ soil), than values reported for a native sandy loam soil (4 to $6 \mu \mathrm{g}$ FDA hydrolyzed/min per g soil) under similar environmental conditions (Davis and Dernoeden, 2002). This would be expected due to the higher levels of organic matter and clay in the native soil or perhaps the long-term, repeated applications of fertilizers in the aforementioned study.

Table 5. The influence of fertilizers and soil amendments on Microdochium patch, superficial fairy ring and bentgrass dead spot in three creeping bentgrass cultivars, 2000 .

\begin{tabular}{|c|c|c|c|c|}
\hline \multirow{2}{*}{ Treatment } & \multicolumn{3}{|c|}{ Plot area diseased (\%) } & \multirow{2}{*}{$\begin{array}{c}\text { Bentgrass } \\
\text { dead spot } \\
\text { infection centers } \\
\text { (no./plot) } \\
\text { 6 Sept. }\end{array}$} \\
\hline & $\begin{array}{c}\text { Microdochium } \\
\text { patch } \\
\text { 31 May }\end{array}$ & \multicolumn{2}{|c|}{$\begin{array}{c}\text { Superficial } \\
\text { fairy ring }\end{array}$} & \\
\hline \multicolumn{5}{|l|}{ Fertilizer-soil amendment } \\
\hline Synthetic fertilizer (SF) surface applied & $8 \mathrm{~b}^{\mathrm{z}}$ & $2 \mathrm{~b}$ & $2 \mathrm{~b}$ & $9 \mathrm{a}$ \\
\hline SF surface + GH incorporated ${ }^{y}$ & $8 \mathrm{~b}$ & $2 \mathrm{~b}$ & $3 \mathrm{~b}$ & $9 \mathrm{a}$ \\
\hline Poultry meal (PM) surface & $16 \mathrm{a}$ & $2 b$ & $3 \mathrm{~b}$ & $3 \mathrm{~b}$ \\
\hline Penn G-2 & $9 \mathrm{a}$ & $1 \mathrm{~b}$ & $1 \mathrm{~b}$ & $9 \mathrm{a}$ \\
\hline Providence & $14 \mathrm{a}$ & $3 \mathrm{a}$ & $3 \mathrm{a}$ & $6 \mathrm{~b}$ \\
\hline Crenshaw & $11 \mathrm{a}$ & $4 \mathrm{a}$ & $5 \mathrm{a}$ & $4 \mathrm{~b}$ \\
\hline \multicolumn{5}{|l|}{ ANOVA } \\
\hline Soil amendment (A) & $*$ & $*$ & $*$ & $* * *$ \\
\hline Cultivar $(\mathrm{C})$ & NS & $*$ & $* * *$ & $* *$ \\
\hline $\mathrm{A} \times \mathrm{C}$ & NS & NS & NS & NS \\
\hline
\end{tabular}

${ }^{2}$ Means in the same column followed by the same letter are not significantly different according to Fishers protected $1 \mathrm{sd}(P=0.05)$.

${ }^{y}$ Granular humate $(\mathrm{GH})$ was incorporated at $2000 \mathrm{~kg} \cdot \mathrm{ha}^{-1}$ into the top $6.5 \mathrm{~cm}$ of the rootzone.

${ }^{x}$ Poultry meal was incorporated at $980 \mathrm{~kg} \cdot \mathrm{ha}^{-1}$ into the top $6.5 \mathrm{~cm}$ of the rootzone.

vs,*,******Nonsignificant or significant at $P=0.05,0.01,0.001$, respectively.

Table 6. Turfgrass quality of three creeping bentgrass cultivars grown on a sand-based rootzone as influenced by fertilizers and soil amendments.

\begin{tabular}{|c|c|c|c|c|c|c|c|c|}
\hline \multirow[b]{3}{*}{ Treatment } & \multicolumn{8}{|c|}{ Quality $^{2}(0$ to 10 scale $)$} \\
\hline & \multicolumn{4}{|c|}{2000} & \multicolumn{4}{|c|}{2001} \\
\hline & Spring & Summer & Fall & Mean & Spring & Summer & Fall & Mean \\
\hline \multicolumn{9}{|l|}{ Fertilizer-soil amendment } \\
\hline SF surface + GH incorporated ${ }^{x}$ & $5.8 \mathrm{ab}$ & $7.5 \mathrm{~b}$ & $8.2 \mathrm{a}$ & $7.1 \mathrm{~b}$ & $6.6 \mathrm{~b}$ & $7.6 \mathrm{a}$ & $7.3 \mathrm{a}$ & $6.5 \mathrm{a}$ \\
\hline Poultry meal (PM) surface & $5.6 \mathrm{~b}$ & $7.3 \mathrm{c}$ & $7.2 \mathrm{~b}$ & $6.6 \mathrm{c}$ & $5.7 \mathrm{c}$ & $6.6 \mathrm{~b}$ & $7.0 \mathrm{a}$ & $5.8 \mathrm{~b}$ \\
\hline PM surface + PM incorporated ${ }^{w}$ & $5.9 \mathrm{a}$ & $7.3 \mathrm{bc}$ & $7.3 \mathrm{~b}$ & $6.7 \mathrm{c}$ & $5.6 \mathrm{c}$ & $6.5 \mathrm{~b}$ & $7.0 \mathrm{a}$ & $5.7 \mathrm{~b}$ \\
\hline \multicolumn{9}{|l|}{ Cultivar } \\
\hline Crenshaw & $5.6 \mathrm{~b}$ & $7.3 \mathrm{~b}$ & $7.5 \mathrm{~b}$ & $6.6 \mathrm{~b}$ & $5.5 \mathrm{c}$ & $6.8 \mathrm{~b}$ & $6.5 \mathrm{c}$ & $5.6 \mathrm{c}$ \\
\hline \multicolumn{9}{|l|}{ ANOVA } \\
\hline Amendment (A) & $* *$ & $* * *$ & $* * *$ & $* * *$ & $* * *$ & $* * *$ & NS & $* * *$ \\
\hline Cultivar $(\mathrm{C})$ & $* * *$ & $* * *$ & $* * *$ & $* * *$ & $* * *$ & $* * *$ & $* * *$ & $* * *$ \\
\hline $\mathrm{A} \times \mathrm{C}$ & NS & NS & NS & NS & NS & NS & NS & NS \\
\hline \multicolumn{9}{|l|}{ Orthogonal contrasts } \\
\hline
\end{tabular}

${ }^{2}$ Turfgrass quality was assessed on a 0 to 10 scale where $0=$ brown or dead turf and $10=$ uniform, optimum green color and density.

'Means in the same column followed by the same letter are not significantly different according to Fisher's protected LSD $(P=0.05)$

${ }^{\mathrm{x}}$ Granular humate $(\mathrm{GH})$ was incorporated at $2000 \mathrm{~kg}^{-} \cdot \mathrm{ha}^{-1}$ into the top $6.5 \mathrm{~cm}$ of the rootzone.

wPoultry meal was incorporated at $980 \mathrm{~kg} \cdot \mathrm{ha}^{-1}$ into the top $6.5 \mathrm{~cm}$ of the rootzone.

Ns,***,****Nonsignificant or significant at $P=0.05,0.01,0.001$, respectively. 
Thatch. Thatch depth increased to $\approx 15 \mathrm{~mm}$ in the first year and an additional $8 \mathrm{~mm}$ during the second year (Table4). Fertilizer/soil amendments had no effect on thatch in 2000, but there were differences on both rating dates in 2001 . Although treatment differences were rather small $(<3 \mathrm{~mm})$, the greatest thatch development occurred in plots subjected to surface-applied SF alone in 2001. Cultivar effects were observed in both years, with 'Penn G-2' having more thatch than either 'Providence' or 'Crenshaw' on two of three rating dates. 'Crenshaw', however, had significantly more thatch than 'Providence' or 'Penn G-2' on 19 Oct. 2001. The reason for this reversal in cultivars is unknown. Orthogonal contrasts showed that plots receiving PM had reduced thatch depths in 2001, when compared to the SF treatments. The slightly reduced thatch levels in PM-treated turf were probably due to the slower rate of establishment or the slow release characteristics of this fertilizer. Similarly, Davis and Dernoeden (2002) observed no agronomically important thatch level differences in response to eight of nine different $\mathrm{N}$ sources applied over 7 years in fairway height $(13 \mathrm{~mm})$ bentgrass grown on native soil. A composted sewage sludge, however, increased thatch when compared to all other $\mathrm{N}$ sources and unfertilized plots in the aforementioned study. Mancino et al. (1993) found that applications of a PM product increased microbial populations in thatch. There was more thatch in plots treated with water-soluble $\mathrm{N}$, when compared to PM, but the difference was only $0.44 \mathrm{~mm}$ after 2 years. They concluded that while PM increased microbial populations it was not very useful in degrading thatch, since there were high levels of indigenous microbes already present. However, in a study involving hybrid bermudagrass (Cynodon dactylon $\times$ transvaalensis Burtt-Davy) putting green turf in Alabama, more thatch was recorded in year 2 of a 2-year study where activated sewage sludge was used, when compared to ammonium nitrate-treated areas (White and Dickens, 1984). Other researchers, however, have reported that a PM-based product helped reduce thatch in kentucky bluegrass ( $\mathrm{Poa}$ pratensis L.) grown on native soil, presumably by increasing earthworm activity (Melvin and Vargas, 1994). Thatch levels probably are influenced by a combination of factors such as turfgrass species and cultivar; growth rate; N-rate, source and timing; mowing height; earthworm activity; and cultivation practices. Therefore, based on our data we cannot definitively say that $\mathrm{N}$ source affected thatch levels.

Disease incidence and severity. In June 2000 , plots were inoculated with an isolate of $O$. agrostis and bentgrass dead spot data were recorded in September (Table 5). Disease severity was judged to be low and each fertilizer-soil amendment treatment had an average of 3 to 9 spots/plot. Bentgrass dead spot was more prevalent in 'Penn G-2' than the other cultivars and disease incidence was more severe in SF-treated plots than PM-treated plots. The mechanism of bentgrass dead spot suppression with PM is unknown and more research regarding the influence of various $\mathrm{N}$ sources on the disease is needed.

Dollar spot was detected in both years of the study, but there were no fertilizer or soil amendment effects on dollar spot incidence or severity (data not shown). Cultivar had a major influence on dollar spot incidence in this study, with 'Crenshaw' sustaining significantly more damage on all rating dates (data not shown). These results were not surprising due to the inherent susceptibility of this cultivar to $S$. homoeocarpa (Abernathy et al., 2001; Bruneau et al., 2001; Engelke et al., 1995; Settle et al., 2001)

Two other diseases were active in the study in 2000, including microdochium patch and superficial fairy ring (Table 5). Microdochium patch was observed in Apr. and an increase in disease severity was noted following the initial fertilizer treatment ( $\mathrm{N}$ at a rate of $24 \mathrm{~kg} \cdot \mathrm{ha}^{-1}$ ) on 15 May. On 31 May, plots treated with PM had significantly more damage than SF-treated plots. There were no cultivar effects. Water soluble $\mathrm{N}$ applications previously have been shown to enhance this disease (Goss and Gould, 1968; Brauen et al., 1975; Raikes et al., 1997). Microdochium patch is favored by abundant moisture (Watschke et al., 1995). Liu et al. (1995), found that applications of the same PM fertilizer used in this study significantly increased thatch moisture when compared to various other fertilizers and an untreated control. Our measurements, however, did not determine soil or thatch moisture content.

Superficial fairy ring developed in July 2000 and disease severity was greatest in PM-incorporated plots combined with surface-applied PM (5\% vs. $2 \%$ to $3 \%$ ). Organisms that cause superficial fairy ring are saprophytic fungi and the presence of the PM-based organic substrate may have enhanced their activity. The GH also is an organic carbon substrate, but it is a relatively stable form of organic matter and therefore much more resistant to degradation than PM. Among cultivars, there was less superficial fairy ring development in 'Penn G-2' than the other two cultivars.

Turfgrass quality. Visual turfgrass quality ratings were initiated the spring following establishment. In both years, quality increased from spring to summer $(P<0.05)$ (Table 6). A decline in the mean yearly turfgrass quality in 2001 occurred in large part due to mechanical damage from topdressing, vertical cutting and core aeration. Surface-applied SF generally provided better quality during Summers 2000 and 2001 and Fall 2000, when compared to the PM programs. Among cultivars, 'Penn G-2' consistently had better turfgrass quality than the other two cultivars throughout the study. This may be because of its finer leaf texture and more aggressive growth habit. 'Providence' exhibited better turfgrass quality on average than 'Crenshaw' in 2001. These results were consistent with previous quality evaluation data for 'Penn G-2' (National Turfgrass Evaluation Program, 1996). Visual ratings of color and verdure are subjective, but it is important to note that the SF treatments generally provided better turfgrass quality than the PM. This is particularly important because many turfgrass managers use this subjective scale to evaluate turfgrass quality and periodically schedule nutrient applications using this information.

\section{Conclusions}

This may be the first study that assessed the effect of natural organic soil amendments on the establishment of bentgrass, seasonal rooting, thatch development, soil microbial activity, disease and turfgrass quality in a newly constructed sand-based rootzone. Establishmen initially was most rapid where SF was used. Thus, it appeared that the most important factor affecting establishment rate was $\mathrm{N}$-availability, since SF treatments had coverage ratings that initially were greater than PM-treated plots. Plots incorporated with PM established more rapidly than plots only receiving PM on the surface. This improved establishment may be attributed to the additional nutrients supplied in PM-incorporated plots. Granular humate preplant-incorporated combined with surface applications of SFinitially increased root length and rootmass density. This effect, however, did not have a noticeable effect on visua turfgrass quality. Additionally, SF generally was associated with improved visual turfgrass quality following establishment in 2000 and 2001. Turf treated with PM was associated with less thatch in the final study year, when compared to SF alone. Plots treated with PM generally had higher levels of microdochium patch, but reduced levels of bentgrass dead spot, when compared to SF-treated turf. Greater soil microbial activity was observed in PM-treated plots during the first 14 month after seeding, however, this attribute did not enhance establishment rate when compared to SF-treatments, nor did it provide for suppression of microdochium patch or superficial fairy ring. Results indicated that there were short-lived benefits from incorporating eithe $\mathrm{PM}$ or GH. The long-term use of PM or SF may affect soil chemistry differently and may play an important role in nutrient availability and soil organic matter levels. These soil properties, however, were not evaluated during this study. The PM fertilizer may be better used as a supplemental $\mathrm{N}$ source for maintenance growth after establishment, as the very slow release properties of PM would limit excessive shoot growth. Incorporation of GH would be expensive, but its initial effect on promoting seedling rooting may be worth the cost to some turf managers.

\section{Literature Cited}

Abernathy, S.D., R.H. White, P.F. Colbaugh, M.C. Engelke, G.R. Taylor, III, and T.C. Hale. 2001. Dollar spot resistance among blends of creeping bentgrass cultivars. Crop Sci. 41:806-809.

Alexander, M. 1977. Introduction to soil microbiology. $2^{\text {nd }}$ ed. Wiley, N.Y.

Beard, J.B. and W.H. Daniel. 1966. Relationship of creeping bentgrass (Agrostis palustris Huds.) root growth to environmental factors in the field. Agron. J. 58:337-339.

Bigelow, C.A., D.C. Bowman, D.K. Cassel, and T.W. Rufty, Jr. 2001. Creeping bentgrass response to inorganic soil amendments and mechanically induced subsurface drainage and aeration. Crop Sci. 41:797-805.

Bigelow, C.A.,A.G. Wollum, II, and D.C. Bowman. 2002. Characterization of microbial properties in newly constructed sand-based rootzones. Crop 


\section{Turf Management}

Sci. 42:1611-1614

Bruneau, A.H., C.A. Bigelow, R.J. Cooper, and D.C Bowman. 2001. Performance of creeping bentgrass cultivars maintained at two mowing heights and under two fungicide regimes in North Carolina. Intl. Turfgrass Soc. Res. J. 9:835-842.

Brauen, S.E, R.L. Goss, C.J. Gould, and S.P. Orton 1975. The effects of sulphur in combinations with nitrogen, phosphorus and potassium on colour and fusarium patch disease of Agrostis putting green turf. 1975. J. Sports Turf Res. Inst. 51:83-91.

Chen, Y. and T. Aviad. 1990. Effects of humic substances on plant growth. p. 161-186. In: P. McCarthy, C.E. Clapp, R.L. Malcolm, and P.R. Bloom (eds.). Humic substances in soil and crop science: Selected readings. SSSA-ASA, Madison, Wis.

Cooper, R.J., C. Liu, and D.S. Fisher. 1998. Influence of humic substances on rooting and nutrient content of creeping bentgrass. Crop Sci 38:1639-1644

Davis, J.G., and P.H. Dernoeden. 2002. Dollar spo severity, tissue nitrogen, and soil microbial activity in bentgrass as influenced by nitrogen source. Crop Sci. 42:480-488.

Dorer, S.P. and C.H. Peacock. 1997. The effects of humate and organic fertilizer on establishment and nutrition of creeping bent putting greens. Intl. Turfgrass Soc. Res. J. 7:437-443.

Elliott, M.L., H.D. Skipper, and E.A. Guertal. 2000. Bacterial populations and diversity within new USGA putting greens. 2000 USGA Turfgras Environ. Res. Summary p. 4, Far Hills, N.J.

Elliot, M.L. and E.A. Des Jardin. 1999. Effect of organic nitrogen fertilizers on microbial populations associated with bermudagrass putting greens. Biol. Fert. Soils 28:431-435.

Elliot, M.L. and E.A. Des Jardin. 2001. Fumigation effects on bacterial populations in new golf course bermudagrass putting greens. Soil Biol. Biochem. 33:1841-1849.

Engelke, M.C., V.G. Lehman, W.R. Kneebone, P.F. Colbaugh, J.A. Reinert, and W.E. Knoop. 1995. Registration of 'Crenshaw' creeping bentgrass. Crop Sci. 35:590.

Goss, R.L. and C.J. Gould. 1968. Some inter-relationships between fertility levels and fusarium patch diseases of turfgrasses. J. Sports Turf Res. Inst. 44:19-26.

Hoyland, B.F. and P.J. Landschoot. 1993. Effect of various nitrogen $(\mathrm{N})$ sources on dollar spot suppression. 1992. Biol. Cult. Tests Control Plant Dis. 8:112.

Huang, B., X. Liu, and J.D. Fry. 1998. Shoot physiological responses of two bentgrass cultivars to high temperature and poor soil aeration. Crop Sci. 38:1219-1244

Kaminski,J.E. and P.H. Dernoeden. 2002. Geographic distribution, cultivar susceptibility, and field observations on bentgrass dead spot. Plant Dis. 86:1253-1259.

Kurtz, K.W. and W.R. Kneebone. 1980. Influence of aeration and genotype upon root growth of creeping bentgrass at supra-optimal temperatures. Int. Turfgrass Soc. Res. J. 3:145-148.

Liu, L.X., T. Hsiang, K. Carey, and J.L. Eggens. 1995. Microbial populations and suppression of dollar spot disease in creeping bentgrass with inorganic and organic amendments. Plant Dis. 79:144-147

Liu, C., R.J. Cooper, and D.C. Bowman. 1998. Humic acid application affects photosynthesis, root development, and nutrient content of creeping bentgrass. HortScience 33:1023-1025.

Mancino, C.F., M. Barakat, and A. Maricic. 1993. Soil and thatch microbial populations in an $80 \%$ sand : $20 \%$ peat creeping bentgrass putting green. HortScience 28:189-191.

Melvin, B.P. and J.M. Vargas, Jr. 1994. Irrigation frequency and fertilizer type influence necrotic ring spot of Kentucky bluegrass. HortScience 29:1028-1030

National Turfgrass Evaluation Program. 1996. 'National Bentgrass Test-1993, Progress report 1993-1996. In: K. Morris (ed.). NTEP 97-6, USDA-ARS, Beltsville, Md.

Nelson, E.B. and C.M. Craft. 1991. Suppression of dollar spot with topdressings amended with composts and organic fertilizers, 1989. Biol. Cult. Tests Control Plant Dis. 6:93.

Nelson, E.B. and C.M. Craft. 1992. Suppression of dollar spot on creeping bentgrass and annual bluegrass turf with compost-amended topdressings. Plant Dis. 76:954-958.

Raikes, C., N.W. Lepp, and P.M. Canaway. 1997. The effect of different nitrogen application levels on disease incidence of five different soccer pitch constructions. Intl. Turfgrass Soc. Res. J. 8:517-531.

Ralston, D.S. and W.H. Daniel. 1972. Effect of temperature and water table depth on the growth of creeping bentgrass roots. Agron. J. 64:709-713

SAS Institute. 1999. SAS user's guide: Statistics. version 8.0. SAS Inst., Cary, N.C.

Schnurer, J. and T. Rosswall. 1982. Fluorescein diacetate hydrolysis as a measure of total microbial activity in soil and litter. Appl. Environ. Microbiol. 43:1256-1261.

Settle, D., J. Fry, and N. Tisserat. 2001. Dollar spot and brown patch fungicide management strategies in four creeping bentgrass cultivars. Crop Sci. 41:1190-1197.

Smiley, R.W., P.H. Dernoeden, and B.B. Clarke. 1992. Compendium of turfgrass diseases. 2nd ed. The American Phytopathological Society, St. Paul, Minn.

Smith, J.D., N. Jackson, and A.R. Woolhouse. 1989. Fungal diseases of amenity turf grasses. E. \& F.N. Spon, New York.

Steel, R.G.D., J.H. Torrie, and D.A. Dickey. 1997. Principles and procedures of statistics: A biometrical approach. $3^{\text {rd }}$ ed. McGraw-Hill, Inc., New York.

Stevenson, F.J. 1994. Humus chemistry: Genesis, composition, reactions. 2nd ed. Wiley, New York

Sweeney, P., K. Danneberger, D. Wang, and M. McBride. 2001. Root weight, nonstructural carbohydrate content and shoot density of highdensity creeping bentgrass cultivars. HortScience 36:368-370.

United States Golf Association Green Section Staff. 1993. Specifications for a method of putting green construction. U.S. Golf Assn., Far Hills, N.J.

Watschke, T.L., P.H. Dernoeden, and D.J. Shetlar. 1995. Managing turfgrass pests. Lewis Publ. Boca Raton, Fla

White, R.H. and R. Dickens. 1984. Thatch accumulation in bermudagrass as influenced by cultura practices. Agron. J. 76:19-22.

$\mathrm{Xu}$, Q. and B. Huang. 2000. Growth and physiological responses of creeping bentgrass to changes in air and soil temperatures. Crop Sci. 40:1363-1368.

Zhang, X. and R.E. Schmidt. 2000. Hormone-containing products' impact on antioxidant status of tall fescue and creeping bentgrass subjected to drought. Crop Sci. 40:1344-1349. 